\title{
Barriers to access healthcare for Middle American Migrants during transit in Mexico ${ }^{1}$
}

\author{
Barreras de acceso a atención médica para Migrantes Centroamericanos \\ durante su tránsito por México
}

\author{
Yessica Elizabet, Llanes-García ${ }^{2}$ \\ https://orcid.org/0000-0003-1750-8057
}

\author{
Tuur, Ghys ${ }^{3}$
}

$\underline{\text { https://orcid.org/0000-0003-4582-5578 }}$

\author{
Universidad Autónoma de Nuevo León, México \\ do) https://doi.org/10.29105/10.29105/pgc7.13-7
}

\begin{abstract}
This paper draws attention to a little discussed aspect of access to healthcare for the hundreds of thousands of migrants that transit through Mexico to reach the United States, which in theory under the old system was covered via Seguro Popular. To inform future debates on the right to health of migrants, this paper analyses semi structured interviews of thirty-one transit migrants in Monterrey to understand the different barriers to healthcare that migrants faced under the former system. The results cover access to information, economic access, physical access, and discrimination. The paper concludes that these barriers are significant, with access to information standing out as the largest challenge. Our policy recommendations mainly center around improving the (information) outreach to migrants.

Keywords: accessibility, healthcare, migration, Seguro Popular, transit.

\section{RESUMEN}

Este documento dirige la atención a un aspecto poco discutido del acceso a la atención médica para los cientos de miles de migrantes que transitan por México para llegar a los Estados Unidos, que en teoría bajo el antiguo sistema estaba cubierto a través del Seguro Popular. Para informar debates futuros sobre el derecho a la salud de los migrantes, este documento analiza entrevistas semiestructuradas de 31 migrantes en tránsito en Monterrey para comprender las diferentes barreras a la atención médica que enfrentaron los migrantes bajo el sistema anterior. Los resultados abarcan el acceso a la información, el acceso económico, el acceso físico y la discriminación. El documento concluye que estas barreras son importantes, destacando el acceso a la información como el mayor desafío. Nuestras recomendaciones de política se centran en mejorar el alcance (de información) a los migrantes.

Palabras claves: accesibilidad, atención médica, migración, Seguro Popular, tránsito.
\end{abstract}

Recibido: 22 de Mayo 2020 - Aceptado: 16 de Julio 2020

Cómo referenciar este artículo:

Llanes-García, Y., L. \& Ghys, T. (2021). Barriers to access healthcare for Middle American Migrants during transit in Mexico. Politica Globalidad y Ciudadanía, 182-204. Recuperado de http://revpoliticas.uanl.mx/ index.php/RPGyC/article/view/172. https://doi.org/10.29105/10.29105/pgc7.13-7

\footnotetext{
1 The results presented in this document are part of the research project on Accessibility to Seguro Popular of Centro American transmigrants in the metropolitan area of Monterrey, initiated at the Universidad Autónoma de Nuevo León in Mexico.

2 Maestrante en Relaciones Internacionales en la Facultad de Ciencias Políticas y Relaciones Internacionales de la Universidad Autónoma de Nuevo León. Email: yessica.llanesga@uanl.edu.mx.

3 Doctor en Sociología por Universiteit Antwerpen, Profesor Investigador de la Facultad de Ciencias Políticas y Relaciones Internacionales de la Universidad Autónoma de Nuevo León. Email: tuur.ghys@uanl.edu.mx
} 


\section{1.- INTRODUCCION}

The so called 'Fourth Transformation' of Mexican public life that started December 2018 came with a questioning of practically every public institution by either civil society, the opposition or the government itself. One highly debated change was in the field of healthcare for the most vulnerable, with the change from the Seguro Popular coverage program to the more encompassing Instituto de Salud para el Bienestar (INSABI). In this paper we draw attention to the little discussed aspect of access to healthcare for the hundreds of thousands of migrants that transit through Mexico to reach the United States, which in theory under the old system was covered via Seguro Popular. To inform future debates on the right to health of migrants, this paper analyses interviews of transmigrants in Monterrey to understand the different barriers to healthcare that migrants faced under the former system. Our results show that these barriers are significant, with access to information standing out as the largest challenge.

In the next section we will discuss the relevance of the right to health in the Mexican context of transmigration, followed by a brief description of the policy context. Next, we outline our analytical framework and methodology. Next the empirical data is laid out in the results section, followed by a concluding discussion.

\section{2.- THEORICAL FRAMEWORK}

\section{Middle American migration context in Mexico}

The relevance of studying the interplay of access to healthcare and migration in Mexico becomes clear when we consider both the volume of migration and the vulnerability of migrants. In the last decade the historically high number of emigrates from Mexico to the U.S. has decreased, while the number of people from the 'Northern Triangle' of Middle America (Honduras, Guatemala and El Salvador) that migrate through Mexico surged (Dominguez, Rietig, 2015; International crisis group, 2016). From the total of migrants presented to migration authorities between January and December 2020, more than the 90\% were from the Northern Triangle (Secretaría De Gobernación, Subsecretaría De Derechos 
Humanos, Población Y Migración, Unidad De Política Migratoria, Registro E Identidad De Personas, 2020). Of these, 44.9\% were from Honduras, 36.2\% from Guatemala and $10.2 \%$ from El Salvador. While this varies per year, and currently decreased due to Covid19 and changes in enforcement (Puiz, 2020), during its peak an estimated 500.000 irregular migrants tried to cross Mexico annually (Médecins Sans Frontières, 2017). These so-called transit migrants will "likely spend months crossing Mexico before they reach the Northern border. This journey is not always unidirectional or continuous" (Frank-Vitale, 2020, p. 59). Although the destination of most of these Central American migrants is the United States, many remain in Mexico because they do not have sufficient resources to cross the northern border, or due to the impossibility of returning to their countries of origin (Cohn et al., cited by Universidad Iberoamericana, 2020). Additionally, during Covid19 period the United States and Guatemala reinforced their borders and migrants were stuck and unable to move north or south (Arriola Vega \& Coraza de los Santos, 2020). According to information from the Instituto Nacional de Migración, (2020) on April 2020, more than 21,000 migrants were stranded in Mexico as a result of the measures taken against Covid19. This implies migrants remain more time in Mexico and make its transit longer than they expected.

This volume of migrants has its own profile, for example, a major part of migrants who transit through Mexico are men, but the number of female migrants has been constantly rising. The number of female migrants apprehended by authorities rose from $13 \%$ in fiscal year 2012 to $25 \%$ in 2017, most of them from the Northern Triangle (Enrique Gómez Ramírez, 2018, p. 114). In relation with age, a report of Red de Documentación de las Organizaciones Defensoras de Migrantes (2019) indicates that age group with most migrants is from 18 to 60 years old; ages considered productive in workspaces. In the last decades, the number of children who migrate has also increased, on the report, from the total of 26,382 surveyed migrants, 3975 were children and teenagers. Those characteristics come with specific health necessities which should be considered on the access to healthcare.

The healthcare needs of middle American Migrants in transit in Mexico

Revista Política, Globalidad y Ciudadanía, Vol. 7 No. 13, Enero - Junio 2021, Universidad Autónoma de Nuevo León, Monterrey, México, ISSN 2395-8448. 182-204. http://revpoliticas.uanl.mx/index.php/RPGyC/article/view/172 
The process of (irregular) migration exposes people to various health risks, and even under the best of conditions, the process "involves a series of events that can be highly traumatizing and that can place migrants at risk" (Carballo, Nerurkar, 2001, p.557). These optimal conditions are not present in Mexico, which on the contrary has been described as a 'death zone' (Kron, 2016) for migrants. Migrants in transit are exposed to a broad spectrum of extreme health threats, including rape, assault, kidnapping, robbery, police abuse, torture, amongst others (Quiroz, 2014; Redodem, 2018; International Crisis group, 2016; Slack, 2019). To this we must add the various environmental factors (dehydration, animals, injury during transport) that come with the journey. Besides the dangers of the journey, the fact that they are (irregular) migrants creates additional vulnerability. For example in some cases they do not seek help when it is needed out of fear of detention (Médecins Sans Frontières, 2019) or because they do not know how to access healthcare. The migrant's health vulnerability includes factors such as the unawareness of, deficit or absence of rights; the process of migratory grief; the lack of social and/or family support; difficulty accessing preventive resources and ignorance of the local health system (Ros Collado, Ollé Rodríguez, 2016). Based on studies in shelters in Guadalajara (Dignidad y Justicia en el Camino, A.C., 2016), San Luis Potosi and Coahuila (Leyva-Flores, et all., 2015), one could estimate that while there is local variance around half the migrants experience some type of health problem during transit. Given both volume and the vulnerability of this population, it is pertinent to study how their access to healthcare is institutionalized in Mexico.

\section{Mexican policy context of the right to health for migrants}

In this section we briefly review some of the legal obligations of Mexico under international and national law towards migrants regarding health, before discussing how this is institutionalized. To start, article 25 of the Universal Declaration of Human Rights states that "Everyone has the right to a standard of living adequate for the health and well-being" (United Nations, 1948). This was specified in binding international law under the International Covenant on Economic, Social and 
Cultural Rights in article 12, which states "the right of everyone to the enjoyment of the highest attainable standard of physical and mental health" (United Nations, 1966). These principles have been repeating in a large number of reports, pacts, interpretations and other 'soft law' documents of international organizations recognized by Mexico. The latest of these is the Global Compact for Safe, Orderly and Regular Migration (United Nations, 2018), which has among its objectives to provide access to basic services for migrants, including healthcare.

Mexico historically suffered from an inconsistency with international obligations because its internal laws allowed for migrants to be neglected in their right to healthcare. While migrants could buy healthcare services, they were not incorporated in any health system. An opening was made with the constitutional reform in 2011, which states that the constitutional human rights would apply to all persons, not just nationals (Collí Ek, 2012). Around the same time, the new Ley de Migración (2011) explicitly stated that migrants have the right to receive medical care.

The rights were only institutionalized in 2014 when migrants gained access to the public health insurance Seguro Popular (Leyva et al, 2015). The original objective of Seguro Popular was to offer financial protection to the population without social security protection (Flamand, 2014). It was designed in 2003 to finance health services divided into a set of basic interventions of first and second level (ambulatory attention and hospitals) and a high cost set for third level attention which is covered by the Fondo de Protección contra Gastos Catastróficos (Marie Knaul et al., 2013). With this incorporation, migrants could regardless of their legal status access health coverage for ninety days, which at the end of its existence covered 294 actions of attention, 633 medicament codes and 37 specific supplies (Comisión Nacional de Protección Social en Salud, 2019).

\section{3.- METHODOLOGY, SAMPLE PERIOD AND DATA USED}

Mexico is notorious for its gab between the formal recognition and the actual enjoyment of human rights (Ghys, 2019). Health is no exception to this, as Sán- 
chez-Torres (2017) remarks there is a difference between offering a service and people being able to use this. Therefore, this research aims to study the accessibility to healthcare, Seguro Popular, by analyzing the perspective of transit migrants in the metropolitan area of Monterrey. Before outlining the methodology, we will briefly discuss the analytical framework on accessibility.

We will conceptualize accessibility to healthcare in line with the human rightsbased approach of the World Health Organization, which divides it into four overlapping dimensions: Information accessibility, physical accessibility, economic accessibility (affordability) and non-discrimination (World Health Organization, 2017).

Information accessibility "includes the right to seek, receive and impart information and ideas concerning health issues" (Office of the High Commissioner for Human Rights, 2000, p.4). It is not only necessary that the Mexican state extents Seguro Popular to migrants, but it must also promote the right by offering migrants all the information they need to enjoy it. The Reglamento De La Ley General De Salud En Materia De Protección Social En Salud (Estados Unidos Mexicanos, 2014) establishes that the individual states will be responsible for performing promotional actions for the incorporation and affiliation of beneficiaries, as well as for informing beneficiaries about their rights and obligations.

Physical accessibility is understood as "the availability of good health services within reasonable reach of those who need them (...) and other aspects of service organization and delivery that allow people to obtain the services when they need them" (Evans, Hsua, \& Boermaa, 2013, p.1). In relation with Seguro Popular, it refers to the physical accessibility of the affiliation process as well as the medical attention from health providers, medicines or auxiliary services. Legally, this responsibility also falls on the state regime, either directly through the "Servicios Estatales de Salud", or indirectly through the establishments for the medical care of others federative entities or institutions of the National Health System. In Nuevo León, outreach campaigns aside, one can approach Seguro Popular via 14 affiliation centers, 24 affiliation 'totems' that work via video call, or by redirection 
via civil organization or municipal services (personal communication with head of affiliation Seguro Popular N.L., 2019).

Economic accessibility refers to the ability to pay for services without financial hardship, considering not only the price of the health services but also indirect and opportunity costs (Evans, Hsua, \& Boermaa, 2013). The mechanism for guaranteeing this is the Sistema de Protección en Salud, by which the states grants access to medical-surgical services, pharmacists and hospital without disbursement at the time of use (Catálogo Universal de Servicios de Salud, 2019). Even if Seguro Popular technically does not have costs to affiliate or acquire certain medical services, there could be undirected costs migrants face as barriers to access, such as for example transport.

Finally, non-discrimination indicates that "health facilities, goods and services must be accessible to all, especially the most vulnerable or marginalized sections of the population, in law and in fact, without discrimination on any of the prohibited grounds" (Office of the High Commissioner for Human Rights, 2000, p.4). Legally healthcare is a right for everyone without distinctions, but in fact this experience can vary. Since this is a 'social' barrier, it is necessary to study the actual interaction of migrants with the healthcare system rather than the legal structure.

Our empirical study is based on interviews with transit migrants encountered in Monterrey, Nuevo León. The Northern city of Monterrey is one of the last big stops on the eastern migration route where migrants can pause and possibly work before moving into border territory. Approaching migrants late in their journey has two advantages for data collection: first, it allows us to still talk to migrants in transit, whom are able to express their experiences better than after arriving (Frank-Vitale, 2020). Second, they have had sufficient time to experience both health risks and medical services.

All interviews took place between March and June 2019 in Monterrey. They were conducted in the street, in places which migrants frequent such as avenues where they sell things or ask for money, or around places they go for assistance like 
streets near churches or shelters. We did not do them in an institutional surrounding (like a shelter), since this would give us a broader sample of migrants (still including, but not limited to shelter visitors), as those inside the shelter system might be above average informed regarding their rights. Additionally, it allowed for more privacy on the migrants end to conduct the interview without authority figures around.

In total 31 interviews were done, 29 of them to men and 2 to women. The discrepancy between sexes can only be partly explained by the demographical composition of the population (in 2017 men outnumbered woman 1 to 4, see Gómez, 2018). It also resulted from the lack of disposition women showed for interviews (all conducted by a woman) when they are part of groups or among their own family, often preferring to let the men talk. This thus accounts for a slight bias in our results to under covering female health risks. The profile of the interviewees is further explained in the results section. Approximately a third part of the interviewed migrants were in groups or with their family at the moment of the interview, the rest was alone.

The interviews were semi-structured (Rubin \& Rubin, 2005), allowing the researcher to cover lists of themes, but it also allows participants to discuss those in a way that suits them, and they may discuss themes or issues not initially identified by the researcher (Dew, 2007). In this way, an inductive approach can be used to learn about the barrier's transmigrants face through the description of their perception of accessibility and in relation to the health problems they face. The anonymous interviews started by asking for personal information about country of origin, age, and medical necessities they have had. From there onwards, questions relate to the four overlapping dimensions of accessibility established earlier. Quotes in this text are all translations from Spanish by the authors. It is important to indicate that even if the research was intended to focus on Seguro Popular, the interview was designed in a flexible way for migrants who did not have experience with the program. This was done by asking about the four overlapping dimensions of accessibility in relation with their experience to healthcare in general, 
only turning to Seguro Popular in case they encountered it. This turned out to be crucial, as the results in the next section indicate that most migrants did not have any contact or in many cases even knowledge of the program. In what follows both summaries and quotations from these interviews will be used to explain the results.

\section{4.- RESULTS}

The results will be shared in three parts: the first part will discuss the profile and health needs of migrants; the second part discusses the accessibility to healthcare in general and the third part shares results on Seguro Popular. To contextualize the following results, we must share one conclusion up front: the migrants of our sample overwhelmingly did not use Seguro Popular, matter of fact only one out of thirty-one interviewees used it.

Profile and medical needs

Graph 1. Country of origin of interviewed migrants

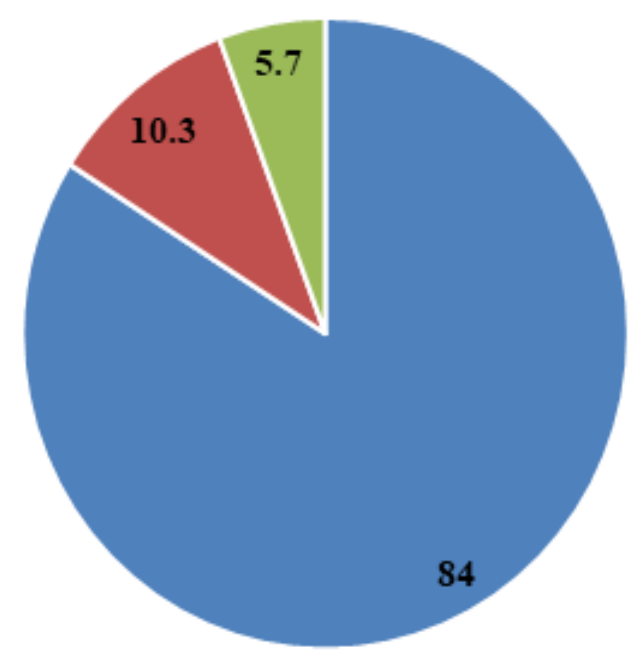

" Honduras " El Salvador " Guatemala

Source: Own elaboration, (2019). 
Amongst the 29 men and 2 women interviewed, the average age was 33, with a minimum of 19 years and a maximum of 64 years old. All interviewed migrants were from the Northern Triangle' of Central America, the majority was from Honduras (26), and the rest was from El Salvador (4) y Guatemala (1). Considering a slight underrepresentation of Guatemalan migrants, it is common across studies and government data to find Hondurans to be the largest group, followed by either El Salvadorians or Guatemalans, depending on the study and year (compare Hernandez, Mora, 2018; ECLAC, 2018; Instituto Nacional de Migración, 2019).

Eighty-seven percent of the interviewed has experienced medical necessities on the road. More than a half mentioned to have general discomfort, which includes common ailments such as flu, fever and pain. The second most recurrent health problem was "road accidents", with falling from trains as the most mentioned road accident (many Migrants ride on cargo trains). And the third one was related to pre and postnatal care, with two births on the road and a case of a transmigrant pregnant woman. Other health problems included gastrointestinal disorders, allergies, laboral accidents, asthma and injuries caused by violence.

From the total of people (n27) who declared they had a medical necessity at least once on the trip, 25.9\% did not receive any kind of medical attention (see graph 1). Migrants who declared to have received medical attention, most frequently indicated shelters as their health care provider. Note that while shelters might in some cases have (visiting) medical staff, they are not technically healthcare services. Private hospitals were the second most mentioned health care provider, followed by public hospitals. Other health care providers mentioned were: Cruz Verde/ Roja, IMSS, Grupo Beta, inside Churches, Seguridad Civil, Caritas, DIF (family services), Centro de Salud (Seguro Popular) and Brigada Estadio (a temporal medical brigade in a stadium). Noteworthy is that the majority (63\%) of medical help experiences was with non-governmental actors, either private hospitals or civil organizations and charities. 
Graph 2. Migrants who declared has had a medical necessity.

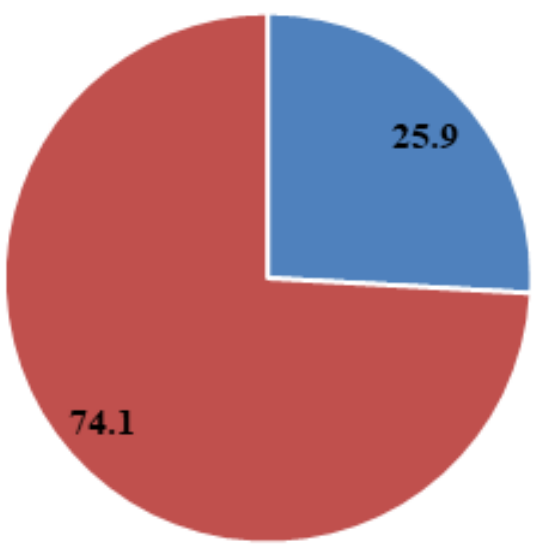

- Migrants who received medical attention $=$ Migrants who did not receive medical attention

Source: Own elaboration, (2019).

Accessibility of general healthcare

We start with the information dimension of accessibility, since the first step in using ones right to health is knowing or even believing one actually has it (see Ros, Ollé, 2016). Various interviewed migrants declared uncertainty related to their right to health, as many believe it is their right (morally), but do not really know if within Mexico it legally is. For example: "I think everyone has right to healthcare, regardless the country, but I do not know how it works here" (Interview, migrant).

Some feel more certain that they have no right to health because of their irregular migratory condition, attributing the help they received to the benevolence: "No, we are usurping a country, it (healthcare) is not a right. We would had the right if we were residents, in that case, it would be a right, but now God just touches their hearth and they help us, even if we do not have the right" (Interview, migrant).

Less than one fifth of the interviewed migrants are aware of their right to health, regardless of if their practical experiences affirmed or contradicted this. Consider the following experiences: 
"I have gone to see the doctors and they tell me I have the right; they do not ask me for money because they tell me it is my right, I can see the doctor at any time" (Interview, migrant).

"Yes, I know I have the right, but it is not in that way, they do not give you attention if you are not Mexican" (interview, migrant).

We conclude that most migrants do not consider themselves as right-holders that both know and believe they could enter the health system, instead seeing the (free) help they receive as charity.

Lack of information on how to access healthcare showed up as a common barrier in the interviews. Migrants often declared they had medical necessities and did not receive health attentions because they do not know where to go. Consider the following experience: "I have partners from Honduras who are sick, they are in Sendero and have children but there is nobody who gives them medical attention, they do not know where to go" (Interview, migrant).

Regarding sources of information on healthcare, the two most mentioned sources of (mis)information were shelters and asking Mexican people on the street, some examples:

"I knew about them (medical centers) because I went to a shelter for migrants" (Interview, migrant).

"I asked mexican people where I could receive medical attention. They told me 'go to hospital \#6, maybe there they could help you' and I went to the hospital but there was no result" (Interview, migrant).

The direct providers of healthcare were also mentioned as an information source, for example the one migrant that has had access to Seguro Popular declared that a 'Centro de Salud' (which forms part of the same state health network) gave her information about the program. The least common sources were media and mi- 
gration authorities. One migrant in our sample declared that migration authorities gave him maps and information about his rights in Mexico when he entered via the frontier. In many cases, migrants did not recognize (or trust) official sources of healthcare information, as in this example: "Not really, for security, we look for police or someone from a shelter, but for health, no" (interview migrant). In general, we conclude that there is a clear lack of information, as well as much disinformation among migrants.

Our results suggest that physical accessibility is partly linked to information, as various migrants didn't know where medical facilities are in the places they passed through. A different problem is that they take dangerous migratory routes that are far away from population centers (thus healthcare) to avoid persecution by police forces. Consider the trouble of the following migrant that tried to avoid migration police by traveling through desolate land: "I fell in Querétaro, in the desert, on the mountain, I could stay there injured (if it had been more serious), because there was nobody to help me (...) In that place there was no one, we were passing thought Hidalgo, and that place is desertic" (interview, migrant).

Experiences of lack of physical access to healthcare in migratory routes makes that migrants take their own precautions, bringing medicines with them from their origin countries. It is important to remark that migratory routes are not just dangerous for being abandoned, but also because they expose migrants to violence. While elaborating on this topic would stray too far from the objective of this paper, our data contains many testimonies regarding the wide spectrum of dangers discussed in the theory section, including multiple accounts of violence by police forces.

In terms of economic accessibility, it is important to point out that migrants can still access healthcare by paying for it (unless they get discriminated, see next section) even if they have no health coverage. Consider the following example: "Someone can buy medicine, a medical consult can be paid in any place, it does not matter if someone is not from here (...) there are pharmacies like Farmacias Benavides" (Interview, migrant). However, it is at least equally frequent that mi- 
grants have difficulties to afford medical attention; one example: "Sometimes, we do not have money to go to a public hospital" (interview, migrant). Some organizations, like the Cruz Roja or Cruz Verde make exceptions and give medical attention to people without money, although our data contains contradictory experiences of this actually being true in practice.

While Seguro Popular is the official institution that should mediate these economical barriers, other intermediate actors (such as shelters) also play a role in providing access, as the following quotes indicates: "Sometimes I arrived at shelters and they gave me pills because I did not have money, I have not entered to a hospital in Mexico because I do not have money" (Interview, migrant). But those shelters which some migrants consider as a support for healthcare access, other migrants see as risk places. Consider the following conversation:

"I do not like to enter to migrant shelters (...) because sometimes there are people who are 'mareros' and I do not trust them. - Do you consider that a pharmacy is a safer place for healthcare? Yes, do you have the economic resources or the facility to access to this service? A little bit. Could it be difficult? Yes, it could be a little difficult, but I think it would be safer" (Interview, migrant, interviewer in italics).

We conclude that economical barriers do exist for most (but not all) migrants, underlying their vulnerability when not covered by healthcare mediators like Seguro Popular or INSABI.

Even if migrants can find and afford help, this does not mean they will receive it. Our interviewees frequently recounted being denied medical care because of their immigration status or being treated differently because of their appearance. Two of the many examples:

"Sometimes it is difficult if they attend us, sometimes it is fast, it depends of the people's hearth, there are many racist people, some of them do not like to see us, they see us badly, other people are not like that, maybe we arrive earlier than 
others to a place but they give preferences to their co-nationals, people from here" (interview, migrant).

"When you go to the pharmacy, they do not want to attend you, even if you have money, sometimes the doctors do not want (...) In Saltillo, Coahuila (...) Farmacias Similares, how they call them, one of these pharmacies (...) They ask me about my documents, where I came from, it is obvious I am not from here, I do not have Mexican documents" (interview, migrant).

Besides not receiving medical attention, some migrants felt mistreated because of their vulnerable position:

"In Tabasco, a doctor treated me badly, he said that he would make a call, he would take me to Migration authorities. He lowered my pants, he told me 'Do you know what? You can get out here, it is easy to take my phone and call migration' (...) Yes, it was for a consult (that he lowered her pants), I was not good of health. I got out crying. (...) I was pregnant with a girl and he told me 'Go back to your country, you come even pregnant', he said 'your daughter could have Down syndrome', he said my daughter could have a big head and I went like crazy. I said we do not have anything to do here, my daughter was born healthy, thanks God (...) in Honduras" (interview, migrant).

Interviewed migrants declared to suffer discrimination in private as well as public facilities, as there are a wide range of actors who discriminate. This lead some of our interviewees to avoid seeking professional medical attention and instead attempt self-medication. Fear and distrust were frequented on interviews as barriers to healthcare access, sometimes because of previous experiences of discrimination and sometimes because of what migrants hear about the risks in Mexico from others. For example, this is a response from a migrant to the question if they sought medical attention: "No, because I am afraid of the major part of people (...) they have told me how Mexico is, being kidnapped, tortured, that is why I am afraid of everyone" (interview, migrant). Although some (including the migrant quoted above) mistrust shelters, they are still most named as mediators that ar- 
range medical appointments and fair treatment for migrants.

Access to Seguro Popular

All interviewees were asked about Seguro Popular if they know it and if they have had access to it. Out of our 31 cases, just one person has had access to Seguro Popular. This concerned a 27-year-old woman from Honduras and her family, who happened to have walked into a health facility ('centro de salud') of the Seguro Popular network and signed up to the program there. Her experience in terms of treatment and economic accessibility was overall positive.

Out of the total interviewed migrants, nineteen had never heard about Seguro Popular (64\%), indicating a sizeable information barrier to accessing a program. The migrants that did declare to know Seguro Popular did not necessarily have correct and complete information about the program. There are various examples of cases in which they know what Seguro Popular is, but they do not know they have the right to access under their irregular status:

"Yes, I have heard about it. (...) They said it benefits people who do not have resources. (...) I really do not know how to get access" (Interview, migrant).

"Yes, I have heard (...) they do not attend you if you do not have documents (...) having a baby in this country, they can help you, if not, they do not help you, it is the only way in which they help you" (Interview, migrant).

"I have heard (about Seguro Popular), but just a little bit, I have not paid attention because I do not have opportunity (...) I have heard they can help you if you become a citizen from here" (interview, migrant).

In total only three people (including the woman that accessed it) had correct information about how the program worked. In general migrants that knew of the existence of the program obtained their (mis)information from listening to others, with only one migrant indicating they learned via media. The predominance of unofficial over official information might indicate migrants look less for official 
sources, as some indicate mistrusting the government.

\section{5.- CONCLUSIONS}

Our general conclusion is that the migrants in our sample did not have information about their right to access to healthcare, and to Seguro Popular. Even if migrants have received healthcare, they see it as charitable actions and not as their right. This turns migrants into passive recipients instead of active participants in their own care. We will first elaborate on this conclusion, before making policy recommendations and addressing current evolutions and future research.

The consequences for evaluating the role of programs like Seguro Popular or their successors are double. On the one hand, it is hard to make a case that they succeed in guaranteeing the enjoyment of human rights of migrants in Mexico. It is an obligation of the authorities to promote the right to health and the mechanisms migrants can use to make it effective, in this case, the right migrants to access to Seguro Popular. Still, our results show that authorities are not a frequent source of information for migrants, instead, migrants obtain information from what they hear on the streets or from shelters.

On the other hand, our limited sample contained frequent testimonies of discrimination and problems with economical accessibility when migrants try to access to healthcare services, even if it is their recognized right to have medical attention from private, social or public providers. Seguro Popular (and now INSABI) is a mechanism the Mexican state has to guarantee migrants the access to healthcare without distinctions because of their migratory situation, race, origin country or any other reason. Programs like these can make an important difference, but it is essential to ensure Seguro Popular personal is trained to attend migrant cases considering their situation of vulnerability.

In order to improve the future accessibility of healthcare beyond the now defunct Seguro Popular, of which the successor still offers a comparable ninety day access to migrants, we offer three general policy recommendations. 
A) Extent the network. While governments tolerate shelters and frequently have informal agreements with them, in the case of Nuevo León there was no formal relation with shelters of the region. However, our empirical evidence indicated that these are one of the main sources of information as well as mediation between migrants and healthcare services. Establishing and reinforcing the relation between shelters and affiliation departments of systems like INSABI, could improve the access to correct and opportune information about programs and rights. The cooperation between government and civil organizations in health concerns has been remarked before by the "Comisión Nacional de los Derechos Humanos" (2019), when it established the importance of civil organization participation in topics like the prevention of HIV.

B) Make information campaigns in key points. Our research indicates that fear, distrust and the fact migrants do not know the surroundings impede their approach to public institutions or social organizations. This agrees with a report done by Doctors of the World (2016) in which it is said that restricting movement constitutes a barrier in seeking access to healthcare and it could be caused by the fear of being arrested. For that reason, it is important to maintain programs like "Seguro en tu camino" and bring information to migrants in key points they frequent. Even if the overall government policy became slightly more outreach based over the past year (Puiz, 2020), more must be done to bring information to migrants as early as possible. In conjunction with the previous point, this can be done in collaboration with actors that are (more) trusted.

C) Training courses regarding transit migrants in public health facilities. In order to avoid cases of discrimination, it is necessary that the staff of both healthcare systems like INSABI and (public) hospitals is made aware of both the rights and needs of the hundreds of thousands of people who migrate across Mexico. This starts with staff on all levels being aware of the right to accessibility migrants have via the program. Yet it would be useful to also spread awareness of the situation of vulnerability and the particular health risks migrants face. 
This recommendation agrees with the World Health Organizations suggestion to "conduct sensitization/awareness trainings, with health care providers and other government officials, about the health needs of migrants and the services available for appropriate referral, considering intercultural differences" (Pan American Health Organization \& World Health Organization, 2019, p. 12).

In terms of further research, our study highlights the role of information in organizing orderly and safe migration. While some have questioned the effectiveness of information campaigns (for example Hiskey et al., 2016), they usually do so from the perspective of deterrence. Yet once on the road information becomes key, not just about generalized conditions, but about routes, preventive measures, and sources of (medical) aid. Future research on the accessibility of the new health system should consider the role information about rights plays with both migrants and service providers.

\section{REFERENCIAS}

Carballo, M. \& Nerurkar, A. (2001). Migration, Refugees, and Health Risks. Emerging Infectious Diseases, 7(7), 556-560.

Collí Ek,V.M. (2012). Improving Human Rights in Mexico: Constitutional Reforms, International Standards, and New Requirements for Judges. Human Rights Brief, 20(1), 7-14.

Comisión Nacional de los Derechos Humanos. (2019). Comunicado de Prensa

DGC/135/19. https://www.cndh.org.mx/sites/all/doc/Comunicados/2019/ Com_2019_135.pdf

Comisión Nacional de Protección Social en Salud. (2019). Catálogo Universal de Servicios de Salud. http://www.documentos.seguropopular.gob.mx/dgss/ CAUSES_2019_Publicaci\%C3\%B3n.pdf

Dew, K. (2007). A health researcher's guide to qualitative methodologies. Australiana and New Zealand Journal of Public Health, 31(5), 433-437. 
Dignidad y Justicia en el camino A.C. (2016). Transit migration through the Guadalajara Metropolitan Area: actors, challenges and perspectives from experience FM4 Paso Libre. El Colegio de la Frontera Norte, A.C. \& Prometeo Editores S.A. de C.V.

Doctors of the World. (2016). International Network 2016 Observatory Report: Access to healthcare for people facing multiple vulnerabilities in health in 31 cities in 12 countries. https://mdmeuroblog.files.wordpress.com/2016/11/ observatory-report2016_en-mdm-international.pdf

Dominguez, R. \& Rietig, V. (2015). Migrants deported from the United States and Mexico to the Northern Triangle. A statistical and Socioeconomic profile. Migration Policy Institute.

ECLAC (2018). Atlas of migration in Northern Central America. ECLAC.

Estados Unidos Mexicanos (2014). Reglamento De La Ley General De Salud En Materia De Protección Social En Salud. Diario Oficial de la Federación, México, 17 de Diciembre de 2014.

Evans, D.B., Hsua, J. \& Boermaa, T. (2013). Universal health coverage and universal Access. Bull World Health Organ, 91, 546-546.

Flamand, L. (2014). Seguro Popular y Federalismo en México: Un análisis de política pública. Centro de Investigación y Docencia Económicas.

Ghys, T. (2019). Spectacular and systematic human rights abuse in Mexico. Politica, Globalidad y Ciudadanía, 5(9), 17-24.

Gómez Ramírez, E. (2018). Migration from Central America. http://www.europarl. europa.eu/RegData/etudes/BRIE/2018/628299/EPRS_BRI(2018)628299_ EN.pdf

Hernandez, R. \& Mora, J. (2018). El drama continua. Perfiles de la migration en tránsito y el desplacamiento forzado en Mexico. In: REDOREM (2018). Procesos Migratorias en México: Nuevos rostros, mismas dinámicas. REDODEM.

Hiskey, J., Cordova, A., Orcés, D. \& Malone, M. (2016). Understanding the Central American Refugee Crisis: Why They Are Fleeing and How U.S. Policies are Failing to Deter Them. American Immigration Council. 
Instituto Nacional de Migración. (2020). Tema Migratorio 140420. https://www.inm.gob.mx/gobmx/word/index.php/tema-migratorio$140420 / \#: \sim:$ text $=$ Varados $\% 2021 \% 20 \mathrm{mil} \% 20 \mathrm{migrantes} \% 20 \mathrm{en} \% 20$ M\%C3\%A9xico\%20por\%201a\%20pandemia\&text=De\%20acuerdo\%20 con $\% 201$ as $\% 20$ estad $\%$ C3\%ADsticas,cuentan $\% 20$ a $\% 209 \% 20 \mathrm{mil} \% 20$ personas.

Leyva Flores, R., Infante, C., Serván-Mori, E., Quintino, F. \& Silverman-Retana, O. (2015). Acceso a servicios de salud para los migrantes centroamericanos en tránsito por México. CANAMID Policy Brief Series, PB05. CIESAS: Guadalajara

Frank-Vitale, A. (2020). Stuck in motion: inhabiting the space of transit of central American migration. The Journal of Latin-American and Caribbean Anthropology, 25(1).

Instituto Nacional de Migración (2019). Boletín No. 179/2019: Población migrante hondureña, en porcentaje, la más atendida por el Instituto Nacional de Migración. https://www.gob.mx/inm/prensa/poblacion-migrante-hondurenaen-porcentaje-la-mas-atendida-por-el-instituto-nacional-de-migracion

International Crisis Group (2016). Easy prey: criminal violence and central American migrants. Brussels: International crisis group.

Knaul, F.M., González-Pier, E., Gómez-Dantés, O., García-Junco, D., ArreolaOrnelas, H., Barraza-Lloréns, M., Sandoval, R., Caballero, F, HernándezÁvila, M., Juan, M., Kershenobich, D., Nigenda, G., Ruelas, E., Sepúlveda, J., Tapia, R., Soberón, G., Chertorivski, S. \& Frenk, J. (2013). Hacia la cobertura universal en salud: protección social para todos en México. Salud pública de México, 55(2), 207- 235.

Kron, S. (2016). Nacimos de la nada: border struggles and maternal politics in Mexico. Citizenship studies, 20(5), 579-594.

Leyva Flores, R., Infante, C., Serván-Mori, E., Quintino, F., \& Silverman-Retana, O. (2015). Acceso a servicios de salud para los migrantes centroamericanos en tránsito por México. https://xiiireuniondemografica.colmex.mx/images/ resumen-extenso/RE_12.14.4.pdf 
Médecins Sans Frontières. (2017). Forced to flee Central America's Northern Triangle: A Neglected Humanitarian Crisis. http://urbanspaces.msf.org/wpcontent/uploads/2019/03/forced-to-flee-central-americas-northern-triangle_a-neglected-humanitarian-crisis.pdf

Médecins Sans Frontières. (2019). Migration policies that kill. https://www.msf. org/migration-policies-kill-mexico

Office of the High Commissioner for Human Rights. (2000). CESCR General Comment No. 14: The Right to the Highest Attainable Standard of Health (Art. 12). https://www.refworld.org/pdfid/4538838d0.pdf

Pan American Health Organization \& World Health Organization. (2019). Guidance Document On Migration And Health. https:/www.paho.org/ hq/index.php?option=com_docman\&view=download\&slug=guidancedocument-on-migration-and-health \&Itemid=270\&lang=en

Puiz, A. (2020). One Year after the U.S. Mexico Agreement. Reshaping Mexico's Migration Policies. Migration Policy Institute.

Quiroz, Y. (2014). Transmigración de centroamericanos por México: su vulnerabilidad y sus derechos humanos. El Colegio de la Frontera Norte.

Ramos García, J.M., Barrachina Lisón, C. \& Ramos, J.E. (2020). The southern border of Mexico: Problems and challenges of national security and its different dimensions. Política, Globalidad y Ciudadanía, 6(12), 102-127.

ReddeDocumentacióndelasOrganizacionesDefensorasdeMigrantes-REDODEM (2019). Migraciones en México: fronteras, omisiones y transgresiones Informe 2019. https://redodem.org/wp-content/uploads/2020/09/REDODEM Informe_2019.pdf

Red de Documentación de las Organizaciones Defensoras de Migrantes REDODEM (2018). Procesos Migratorias en México: Nuevos rostros, mismas dinámicas. http://redodem.org/wp-content/uploads/2019/09/REDODEMInforme-2018.pdf

Ros Collado, M. \& Ollé Rodríguez, C. (2016). Acceso y utilización de los servicios de salud: atención al paciente inmigrante, dificultades y posibles soluciones. In López Fernández, F.J. Gestión Pública de la Salud. 
Rubin, H.J. \& Rubin, I.S. (2005). Qualitative interviewing. The art of hearing data (2nd ed.). Thousand Oaks, CA: Sage Publications Inc.

Sánchez-Torres, D.A. (2017). Accesibilidad a los servicios de salud: debate teórico sobre determinantes e implicaciones en la política pública de salud. Revista Médica del Instituto Mexicano del Seguro Social, 55(1), 82-88.

Slack, J. (2019). Deported to death. How drug violence is changing migration on the US-Mexico border. University of California Press.

Secretaría De Gobernación, Subsecretaría de Derechos Humanos, Población y Migración, Unidad de Política Migratoria, Registro e Identidad de Personas. (2020). Sintesis 2020. Estadísticas Migratorias. http://portales.segob.gob. $\mathrm{mx} /$ work/models/PoliticaMigratoria/CEM/Estadisticas/Sintesis_Graficas/ Sintesis_2020.pdf

United Nations. (1948). Universal Declaration of Human Rights. United Nations. https://www.un.org/en/universal-declaration-human-rights/

United Nations. (1966). International Covenant on Economic, Social and Cultural Rights. United Nations. https://www.ohchr.org/en/professionalinterest/pages/ cescr.aspx

United Nations. (2018). Global Compactfor Safe, Orderly and Regular Migration. United Nationos. https://www.iom.int/global-compact-migration

Universidad Iberoamericana Ciudad de México. (2020). Posicionamiento sobre el contexto migratorio en México.

https://ibero.mx/sites/default/files/posicionamiento_migratorio_1.pdf

World Health Organization. (2017). Human rights and health. https://www.who. int/news-room/fact-sheets/detail/human-rights-and-health 